\title{
Kakeksia Kardiak: Implikasi Klinis, Prevensi, dan Tatalaksana
}

\author{
Sidhi Laksono ${ }^{1,2^{*}}$, Reynaldo Halomoan ${ }^{3}$ \\ ${ }^{1}$ Kepala Laboratorium Katerisasi Kardiak, Departemen Kardiologi dan Vaskular, RSUD \\ Pasar Rebo, Jakarta Timur \\ ${ }^{2}$ Fakultas Kedokteran, Universitas Muhammadiyah Prof. DR. Hamka, Tangerang, \\ Indonesia \\ ${ }^{3}$ Fakultas Kedokteran dan Ilmu Kesehatan, Universitas Katolik Indonesia Atma Jaya, \\ Jakarta, Indonesia. \\ sidhilaksono@uhamka.ac.id*
}

\begin{abstract}
Patients with cardiovascular diseases such as chronic heart failure may develop cardiac cachexia. This occurs due to various mechanisms associated with pathological processes in the heart. The incidence of cardiac cachexia is also a marker of poor prognosis in patients. This condition is characterized by weight loss in patients and a decrease in muscle mass. We conducted a manual search method to find the topic-related article. A total of 30 relevant works of literature were studied. We aimed to understand the role of cardiac cachexia on the physiological function and its proper management. From our study, it was found that systemic inflammation had a role in the development of cardiac cachexia. The presence of cardiac cachexia is associated with the disruption in several systems such as cardiovascular, gastrointestinal, and also the immune system. Strategies for prevention and appropriate management will reduce the incidence of this event. The treatment given can be pharmacological and non-pharmacological. In conclusion, cardiac cachexia impairs the functional capacity of the patient. Proper management can reduce the mortality and morbidity in patients with cardiac cachexia.
\end{abstract}

Keywords: Cardiac cachexia, physiological function, preventive and management

PENDAHULUAN

Kakeksia kardiak merupakan salah satu komplikasi yang dapat dialami oleh pasien dengan penyakit kardiovaskular seperti gagal jantung kronis. Kejadian kakeksia kardiak dikaitkan dengan prognosis yang kurang baik pada pasien terlepas dari fungsi sistolik serta kapasitas fungsional. Kakeksia kardiak dialami oleh sebanyak $8-42 \%$ pasien pada beberapa studi tentang gagal jantung dan tingkat mortalitas tahunan pada pasien dengan kakeksia kardiak dapat mencapai 20-30\% (von Haehling and Anker, 2010; Von Haehling and Anker, 2015). Kakeksia kardiak ditandai dengan adanya penurunan berat badan pada pasien.

Perkembangan kakeksia kardiak dihubungkan dengan proses remodeling pada jantung. Gangguan pada fungsi dan struktur jantung akan memicu terjadinya remodeling melalui aktivasi proses 
inflamasi (Riehle and Bauersachs, 2019). Keadaan inflamasi kronis hadir dan berkaitan dengan malnutrisi pada pasien karena adanya gangguan absorbs nutrien sehingga mengganggu status nutrisi pasien. Kakeksia kardiak menjadi hal yang penting untuk diperhatikan karena dapat mengurangi tingkat kesintasan pasien terlepas dari usia, derajat keparahan gagal jantung, ejeksi fraksi, dan kemampuan fisik (Rossignol et al., 2015). Artikel ini bertujuan untuk memahami kakeksia kardiak mulai dari definisi, mekanisme, implikasi klinis, hingga strategi manajemen. $\mathrm{Hal}$ ini akan membantu klinisi dalam memberikan pelayanan yang baik pada pasien kakeksia kardiak.

\section{DEFINISI}

Secara umum,kakeksia merupakan penurunan berat badan $>5 \%$ tanpa edema dan tidak disengaja dalam kurun waktu 12 bulan terakhir (atau indeks massa tubuh < $20 \mathrm{~kg} / \mathrm{m}^{2}$ ) pada seseorang dengan penyakit kronik dan terdapat setidaknya 3 kriteria klinis atau laboratorium seperti adanya penurunan kekuatan otot, kelelahan, anoreksia, infeks massa bebas lemak yang rendah, dan adanya peningkatan penanda inflamasi (interleukin-6, C-reactive protein), anemia, dan serum albumin yang rendah (Evans et al., 2008). Pada sistem kardiovaskular, proses patologis yang berkaitan dengan terjadinya inflamasi dapat menyebabkan terjadinya kakeksia. Sedikit berbeda dalam hal durasi dengan definisi kakeksia secara umum, Pocock et al. mendefinisikan kakeksia kardiak sebagai penurunan berat badan $>5 \%$ tanpa adanya edema dan tidak disengaja selama periode $\geq 6$ bulan (Pocock et al., 2008). Kakeksia kardiak tidak hanya mempengaruhi massa bebas lemak, namun juga mempengaruhi massa tulang dan massa lemak (Anker, Steinborn, Strassburg, 2004)

MEKANISME

KAKEKSIA KARDIAK

Proses terjadinya kakeksia kardiak merupakan sebuah proses yang kompleks. Beberapa mekanisme terkait dengan perkembangan terjadinya keadaan ini (Freeman, 2009)

\section{Peningkatan kebutuhan energi}

Pasien dengan gagal jantung kronik memiliki kebutuhan energi yang tinggi terkait adanya inflamasi, takikardia, aktivasi simpatetik, dan peningkatan usaha napas. Gagal jantung kronik merupakan sebuah proses katabolikdan ketidakseimbangan dengan proses anabolic berperan dalam mekanisme ini. 


\section{Penurunan absorpsi nutrisi}

Gangguan penyerapan nutrisi disebabkan karena adanya peningkatan kolagen dan penebalan dinding usus sehingga meperpanjang jarak antara dinding kapiler dengan membrane enterosit sehingga mengganggu perfusi dan absorpsi, Selain itu, hal-hal tersebut dapat menyebabkan translokasi endotoksin dari usus melalui mukosa ke sistemik sehingga dapat menyebabkan inflamasi sistemik. (Arutyunov et al., 2008; Sundaram and Fang, 2016).

\section{Penurunan asupan energi}

Penurunan asupan ini berkaitan dengan sistem neurohormonal yang berkaitan dengan faktor neurohormonal. Ghrelin adalah salah satu faktor yang berperan dalam proses asupan makanan. Pada keadaan kakeksia, terdapat perubahan pada hormon yang mengatur napsu makan. Ghrelin yang meningkat akan meningkatkan napsu makan, namun terdapat peningkatan dari hormon yang mengatur rasa kenyang seperti insulin sehingga terjadi ketidakseimbangan hormonal (Laviano et al., 2008). Pada pasien gagal jantung kronik, peningkatan kadar ghrelin yang diikuti dengan penurunan asupan makanan dapat menyebabkan resistensi ghrelin. Hal ini juga berkontribusi dengan terjadinya kakeksia (Lund et al., 2009).

\section{Aktivasi inflamasi}

Translokasi endotoksin yang menyebabkan inflamasi sistemik akan meningkatkan aktivasi sitokin proinflamasi. TNF- $\alpha$ dan IL-1 merupakan faktor yang terlibat dalam terjadinya kakeksia karena menyebabkan anoreksia, peningkatan metabolisme, meningkatkan laju penurunan massa tubuh tanpa lemak, dan menurunkan regenerasi sel otot (Freeman, 2009; Moresi et al., 2008)

\section{IMPLIKASI KLINIS}

Kakeksia kardiak akan menyebabkan pasien mengalami beberapa gangguan pada tubuh terkait penurunan berat badan dan adanya inflamasi. Pada kondisi ini, pasien akan mengalami pengurangan jaringan pada lemak, dan massa yang bebas lemak (lean tissue). Ketidakseimbangan sintesis dan degradasi massa otot skeletal juga akan menyebabkan atrofi otot sehingga terjadi penurunan kekuatan pada pasien dan mengganggu aktivitas (Damatto et al., 2013; Martinez et al., 2010).

Kakeksia kardiak dapat menurunkan fungsi sistem imun. Hal ini dapat berkaitan dengan peningkatan risiko infeksi pada pasien dengan gagal jantung. Protein dan energi yang tidak terdistribusi 
dengan cukup juga akan mengganggu kemampuan tubuh dalam menjaga fungsi pertahanan (Rahman et al., 2016). Penurunan berat badan sendiri tanpa disertai inflamasi berhubungan dengan penurunan fungsi organ seperti organ kardiovaskular, gastrointestinal, anemia, perubahan fungsi respirasi, penurunan laju penyembuhan pada jaringan. Gangguan sistem pernapasan dikaitkan dengan peningkatan katabolisme sehingga kekuatan otot respiratorius akan berkurang.

Kongesti usus dihubungkan dengan kejadian kakeksia kardiak. Hal ini akan menyebabkan terjadinya translokasi bakteri intestinal dan aktivasi sistem imun. Lipopolisakarida, yang merupakan endotoksin bakterial, akan memicu ekspresi dari sitokin pro-inflamasi seperti faktor nekrosis tumor- $\alpha$ (TNF- $\alpha)$ (Valentova et al., 2016).

Anemia defisiensi besi merupakan salah satu jenis anemia yang sering muncul pada pasien gagal jantung dengan prevalensi mencapai $44 \%$ tergantung derajat keparahan kasus. Defisiensi besi dapat menyebabkan dilatasi ventrikel kiri, memicu terjadinya perubahan mitokondrial dan struktural pada jantung, mengganggu fungsi jantung, menyebabkan trombositosis, dan stimulasi sistem saraf simpatis (Arora and Ghali, 2014; Habedank et al., 2013; Okoshi et al., 2014).

\section{PREVENSI dan TATALAKSANA}

Penatalaksanaan pada kakeksia kardiak bersifat multifaktorial. Strategi tatalaksana bertujuan untuk memenuhi kebutuhan nutrisi pasien, mengurangi translokasi bakteri usus, menambah napsu makan, dan mengobati anemia defisiensi besi. Tatalaksana yang diberikan pada pasien meliputi aspek farmakologis dan non-farmakologis.

\section{Pemberian nutrisi}

Pemberian nutrisi diberikan dengan tujuan untuk menjaga berat badan pada tingkat dalam atau sedikit di bawah rentang normal. Jumlah kalori harian direkomendasikan berkisar pada rentang $31.8-35 \mathrm{kkal} / \mathrm{kgBB} / \mathrm{hari}$ untuk meningkatkan massa tanpa lemak pada pasien gagal jantung. Tata cara pemberian nutrisi dilakukan secara perlahan dimulai dengan porsi kecil dan kemudian ditingkatkan hingga mencapai berat badan yang diinginkan. Pemberian nutrisi tidak boleh berlebihan karena akan meningkatkan katekolamin dan kadar insulin dalam plasma, sehingga menyebabkan stress fisiologis (Okoshi et al., 2017). 
Studi oleh Pinho et al membahas rekomendasi asupan energi untuk pasien dengan kakeksia kardiak. Asupan energi untuk pasien dapat diberikan sebanyak 3040 kalori/kgBB/hari. Asupan energi terdiri dari karbohidrat sebesar $50-55 \%$ dari kebutuhan kalori total, lemak sebesar 30$35 \%$, dan kebutuhan protein sebanyak 1.52 gram/kgBB/hari (Pinho and da Silveira, 2014). Pola hidup dan diet yang memicu inflamasi seperti gula, lemak jenuh, lemak trans (margarin), alkohol, dan rokok harus dihindari. Konsumsi sodium juga perlu dikurangi. Sodium dapat diberikan sekitar 0.5-2 gram/hari (Okoshi et al., 2017).

Diet yang bersifat anti-inflamasi seperti suplemen minyak ikan, ikan, zaitun, buah, sayuran, suplemen antioksidan (vitamin B, C, D, dan E), suplementasi zink, magnesium, zat besi, makanan tinggi protein, dan olahraga teratur dapat dianjurkan pada pasien. Belum ada rekomendasi dosis pemberian suplemen vitamin dan mineral. Namun, pemberiannya berkaitan dengan perbaikan fungsi ejeksi ventrikel kiri dan kualitas hidup pasien. (Krim et al., 2013; Rozentryt et al., 2010). Suplementasi omega 3 dapat diberikan karena dapat mengurangi efek inflamasi dan mortalitas pada pasien (Nodari et al., 2011). Pada sebuah uji coba terkontrol placebo, secara acak, dan tersamar ganda, pemberian omega 3 sebanyak 1 gram mengurangi mortalitas sebesar 9\% (Romagna, 2008).

\section{Olahraga}

Olahraga merupakan salah satu terapi non-farmakologis untuk mencegah penurunan massa otot dan remodeling kardiak. Melalui olahraga, akan terjadi penurunan stress oksidatif, penurunan ekspresi sitokin proinflamasi pada otot skeletal, peningkatan kapasitas fungsional, serta perbaikan fungsi ventrikel pada kegiatan aerobic (Alves et al., 2015; Negrao et al., 2015).

\section{Terapi Farmakologis}

Pemberian terapi farmakologis bervariasi dan disesuaikan dengan mekanisme terjadinya kakeksia. Beberapa obat masih dalam pengujian sehingga belum dapat diberikan pada pasien. Pemberian stimulan untuk napsu makan seperti megestrol asetat dapat diberikan pada kondisi kakeksia, namun penggunaannya pada kardiak kakeksia masih belum disetujui. Megestrol dapat meningkatkan massa dan kekuatan otot skeletal. Agen stimulan napsu makan lainnya adalah kanabinoid dan ghrelin. Kanabinoid bekerja melalui reseptor endorfin dan akan menekan sintesis prostaglandin. Ghrelin dapat meningkatkan napsu makan dan juga 
memperbaiki fungsi ventrikel pada pasien (Loncar et al., 2016).

Inflamasi adalah salah satu faktor penting dalam terjadinya kakeksia kardiak. Pemberian agen imunomodulator dapat dipertimbangkan, antara lain seperti pentoksifilin, thalidomide, antagonis IL-1, $\mathrm{N}$-asetilsistein, dan metotreksat. Pemberian inhibitor miostatin, bortezomide, inhibitor lipopolisakarida, dan penghambat melanokortin berperan dalam meningkatkan dan menjaga massa otot pada kardiak kakeksia. Namun, penggunaannya sebagai terapi masih dalam tahap pengujian (Okoshi et al., 2017).

Terapi farmakologis lain adalah menggunakan diuretik untuk mengurangi peningkatan kadar endotoksin pada pasien gagal jantung dengan edema perifer, metoklopramid untuk mengurangi terjadinya translokasi bakteri, serta inhibitor enzim pengkonversi angiotensin dan penghambat reseptor angiotensin untuk mencegah degradasi otot karena angiotensin II berkaitan dengan peningkatan stress oksidatif dan pemecahan protein (Azhar and Wei, 2013; Krim et al., 2013).

\section{KESIMPULAN}

Kakeksia kardiak menyebabkan berbagai gangguan pada sistem fisiologis manusia seperti sistem kardiovaskular, gastrointestinal, dan sistem imun. Hal ini akan meningkatkan morbiditas dan mortalitas pada pasien. Tatalaksana yang tepat dimulai dengan memberikan asupan nutrisi sesuai dengan kebutuhan pasien dengan kakeksia kardiak. Uji terhadap agen farmakologis masih perlu dilakukan untuk menilai efikasi dan keamanan pada pasien.

\section{DAFTAR PUSTAKA}

Alves, C.R.R., da Cunha, T.F., da Paixão, N.A., Brum, P.C., 2015. Aerobic exercise training as therapy for cardiac and cancer cachexia. Life Sci. $125,9-14$

Anker, S., Steinborn, W., Strassburg, S., 2004. Cardiac cachexia. Ann. Med. $36,518-529$.

Arora, N.P., Ghali, J.K., 2014. Anemia and iron deficiency in heart failure. Heart Fail. Clin. 10, 281-294.

Arutyunov, G.P., Kostyukevich, O.I., Serov, R.A., Rylova, N. V, Bylova, N.A., 2008. Collagen accumulation and dysfunctional mucosal barrier of the small intestine in patients with chronic heart failure. Int. J. Cardiol. 125, 240-245.

Azhar, G., Wei, J.Y., 2013. New approaches to treating cardiac cachexia in the older patient. Curr. Cardiovasc. Risk Rep. 7, 480-484.

Damatto, R.L., Martinez, P.F., Lima, A.R.R., Cezar, M.D.M., Campos, D.H.S., Junior, S.A.O., et al, 2013. Heart failure-induced skeletal myopathy in spontaneously hypertensive rats. Int. J. Cardiol. 167, 698-703.

Evans, W.J., Morley, J.E., Argilés, J., Bales, C., Baracos, V., Guttridge, D., et al, 2008. Cachexia: a new 
definition. Clin. Nutr. 27, 793-799.

Freeman, L.M., $2009 . \quad$ The pathophysiology of cardiac cachexia. Curr. Opin. Support. Palliat. Care 3, 276-281.

Habedank, D., Meyer, F.J., Hetzer, R., Anker, S.D., Ewert, R., 2013. Relation of respiratory muscle strength, cachexia and survival in severe chronic heart failure. J. Cachexia. Sarcopenia Muscle 4, 277-285.

Krim, S.R., Campbell, P., Lavie, C.J., Ventura, H., 2013. Micronutrients in chronic heart failure. Curr. Heart Fail. Rep. 10, 46-53.

Laviano, A., Inui, A., Marks, D.L. Meguid, M.M., Pichard, C., Rossi Fanelli, F.,et al, 2008. Neural control of the anorexia-cachexia syndrome. Am. J. Physiol. Metab. 295, E1000E1008.

Loncar, G., Springer, J., Anker, M., Doehner, W., Lainscak, M., 2016. Cardiac cachexia: hic et nunc. J Cachexia. Sarcopenia Muscle 7, 246-260.

Lund, L.H., Williams, J.J., Freda, P., LaManca, J.J., LeJemtel, T.H., Mancini, D.M., 2009. Ghrelin resistance occurs in severe heart failure and resolves after heart transplantation. Eur. J. Heart Fail. 11, 789-794.

Martinez, P.F., Okoshi, K., Zornoff, L.A.M., Carvalho, R.F., Junior, S.A.O., Lima, A.R.R., et al, 2010. Chronic heart failure-induced skeletal muscle atrophy, necrosis, and changes in myogenic regulatiory factors. Med. Sci. Monit. 16, BR374BR383.

Moresi, V., Pristerà, A., Scicchitano, B.M., Molinaro, M., Teodori, L., Sassoon, D., et al, 2008. Tumor necrosis factor- $\alpha$ inhibition of skeletal muscle regeneration is mediated by a caspase-dependent stem cell response. Stem Cells 26, 997-1008.

Negrao, C.E., Middlekauff, H.R., GomesSantos, I.L., Antunes-Correa, L.M., 2015. Effects of exercise training on neurovascular control and skeletal myopathy in systolic heart failure. Am. J. Physiol. Circ. Physiol. 308, H792-H802.

Nodari, S., Triggiani, M., Campia, U., Manerba, A., Milesi, G., Cesana, B.M., et al, 2011. Effects of n-3 polyunsaturated fatty acids on left ventricular function and functional capacity in patients with dilated cardiomyopathy. J. Am. Coll. Cardiol. 57, 870-879.

Okoshi, M.P., Capalbo, R.V., Romeiro, F.G., Okoshi, K., 2017. Cardiac cachexia: perspectives for prevention and treatment. Arq. Bras. Cardiol. 108, 74-80.

Okoshi, M.P., Romeiro, F.G., Martinez, P.F., Oliveira Junior, S.A. de, Polegato, B.F., Okoshi, K., 2014. Cardiac cachexia and muscle wasting: definition, physiopathology, and clinical consequences. Res. Reports Clin. Cardiol. 319-326.

Pinho, C.P.S., da Silveira, A.C., 2014. Nutritional aspects in heart failure. $\mathrm{J}$ Nutr Heal. Sci 1, 305.

Pocock, S.J., McMurray, J.J. V, Dobson, J., Yusuf, S., Granger, C.B., Michelson, E.L., et al, 2008. Weight loss and mortality risk in patients with chronic heart failure in the candesartan in heart failure: assessment of reduction in mortality and morbidity

(CHARM) programme. Eur. Heart J. 29, 26412650.

Rahman, A., Jafry, S., Jeejeebhoy, K., Nagpal, A.D., Pisani, B., Agarwala, R., 2016. Malnutrition and cachexia in heart failure. J. Parenter. Enter. Nutr. 40, 475-486.

Riehle, C., Bauersachs, J., 2019. Key 
inflammatory mechanisms underlying heart failure. Herz 44, 96106.

Romagna, E., 2008. Effect of n-3 polyunsaturated fatty acids in patients with chronic heart failure (the GISSI-HF trial): a randomised, double-blind, placebo-controlled trial.

Rossignol, P., Masson, S., Barlera, S., Girerd, N., Castelnovo, A., Zannad, F., et al, 2015. Loss in body weight is an independent prognostic factor for mortality in chronic heart failure: insights from the GISSI-HF and ValHeFT trials. Eur. J. Heart Fail. 17, 424-433.

Rozentryt, P., von Haehling, S., Lainscak, M., Nowak, J.U., Kalantar-Zadeh, K., Polonski, L., et al, 2010. The effects of a high-caloric protein-rich oral nutritional supplement in patients with chronic heart failure and cachexia on quality of life, body composition, and inflammation markers: a randomized, double-blind pilot study. J. Cachexia. Sarcopenia Muscle 1, 35-42.

Sundaram, V., Fang, J.C., 2016. Gastrointestinal and liver issues in heart failure. Circulation 133, 16961703.

Valentova, M., von Haehling, S., Bauditz, J., Doehner, W., Ebner, N., Bekfani, T.,et al, 2016. Intestinal congestion and right ventricular dysfunction: a link with appetite loss, inflammation, and cachexia in chronic heart failure. Eur. Heart J. 37, 1684-1691.

von Haehling, S., Anker, S.D., 2010. Cachexia as a major underestimated and unmet medical need: facts and numbers.

Von Haehling, S., Anker, S.D., 2015. Treatment of cachexia: an overview of recent developments. Int. J. Cardiol. 184, 736-742. 